\title{
Towards an Efficient Generalization of the Online Dosage of Hydrogen Peroxide in Photo-Fenton Process to Treat Industrial Wastewater
}

\author{
Xiangwei Yu ${ }^{1}$, Alejandro Cabrera-Reina ${ }^{2, *}$, Moisès Graells ${ }^{1}$, Sara Miralles-Cuevas ${ }^{3}$ and \\ Montserrat Pérez-Moya ${ }^{1, *}$
}

check for

updates

Citation: Yu, X.; Cabrera-Reina, A.; Graells, M.; Miralles-Cuevas, S.;

Pérez-Moya, M. Towards an Efficient Generalization of the Online Dosage of Hydrogen Peroxide in

Photo-Fenton Process to Treat Industrial Wastewater. Int. J. Environ. Res. Public Health 2021, 18, 13313. https://doi.org/10.3390/ ijerph182413313

Academic Editor: Barbara Ruffino

Received: 20 October 2021

Accepted: 12 December 2021

Published: 17 December 2021

Publisher's Note: MDPI stays neutral with regard to jurisdictional claims in published maps and institutional affiliations.

Copyright: (c) 2021 by the authors. Licensee MDPI, Basel, Switzerland. This article is an open access article distributed under the terms and conditions of the Creative Commons Attribution (CC BY) license (https:/ / creativecommons.org/licenses/by/ $4.0 /)$.
1 Chemical Engineering Department, Escola d'Enginyeria de Barcelona Est (EEBE), Universitat Politècnica de Catalunya, Av. Eduard Maristany, 16, 08019 Barcelona, Catalonia, Spain; xiangwei.yu@upc.edu (X.Y.); moises.graells@upc.edu (M.G.)

2 Programa Institucional de Fomento a la Investigación, Desarrollo e Innovación (PIDi), Universidad Tecnológica Metropolitana, Santiago 8940000, Chile

3 Plataforma Solar de Almería-CIEMAT, Ctra Senés km 4, 04200 Taverns, Almeria, Spain; sara.miralles@ual.es

* Correspondence: acabrerar@utem.cl (A.C.-R.); montserrat.perez-moya@upc.edu (M.P.-M.)

\begin{abstract}
This work addresses the dosage of $\mathrm{H}_{2} \mathrm{O}_{2}$ in photo-Fenton processes and the monitoring of Dissolved oxygen (DO) that can be used to drive the dosage of $\mathrm{H}_{2} \mathrm{O}_{2}$. The objective of this work is to show that a smarter monitoring of a process variable such as DO (for which on-line measurement can be inexpensively obtained) enables the proposal and implementation of efficient dosage strategies. The work explores the application of a recent proposed strategy consisting of: (i) initial $\mathrm{H}_{2} \mathrm{O}_{2}$ addition, (ii) continuous $\mathrm{H}_{2} \mathrm{O}_{2}$ addition until a DO set up is reached, and (iii) automatic $\mathrm{H}_{2} \mathrm{O}_{2}$ addition by an on-off control system based on DO slope monitoring, and applies it to the treatment of different individual contaminants and their mixtures (paracetamol and sulfamethazine). The assays performed following this dosage strategy showed improved values of TOC removed per $\mathrm{H}_{2} \mathrm{O}_{2}$ consumed. For the case of sulfamethazine, this improvement increased up to $25-35 \%$ with respect to the efficiency obtained without dosage. Furthermore, a deeper analysis of the results allowed detecting and assessing the opportunity to redesign the dosage scheme and reduce its complexity and the number of control parameters. The promising results obtained are discussed in regard of future research into further increasing the simplicity and robustness of this generalized control strategy that improves the applicability of the photo-Fenton process by reducing its operating costs and increasing automation.
\end{abstract}

Keywords: photo-Fenton process; hydrogen peroxide dosage; dissolved oxygen; control; wastewater; paracetamol; sulfamethazine

\section{Introduction}

Since the early work by Henry Fenton in the 1890s, the study of the application of Fenton and photo-Fenton processes to the degradation of refractory organic pollutants has developed increasing attention, especially over the last decades. Particularly, the Fenton process is an effective method that consists of the reaction between Fenton reagents, $\mathrm{Fe}^{2+}$ (catalyst) and hydrogen peroxide $\left(\mathrm{H}_{2} \mathrm{O}_{2}\right)$, yielding hydroxyl radical $(\mathrm{HO})$ and $\mathrm{Fe}^{3+}$ (Reaction 1). Due to the low reaction rate between $\mathrm{Fe}^{3+}$ and $\mathrm{H}_{2} \mathrm{O}_{2}$, the Fenton reaction is boosted with UV radiation (Reaction 2), improving the continuous production of $H O$, [1] This highly reactive species unselectively reacts with organic matter $(\mathrm{M})$, producing organic intermediates and, eventually, its complete mineralization (Reaction 3) when adequate operation conditions are selected.

$$
\mathrm{Fe}^{2+}+\mathrm{H}_{2} \mathrm{O}_{2} \rightarrow \mathrm{Fe}^{3+}+\mathrm{HO}^{-}+\mathrm{HO} \bullet
$$




$$
\begin{gathered}
\mathrm{Fe}^{3+}+\mathrm{H}_{2} \mathrm{O}+\mathrm{hv} \rightarrow \mathrm{Fe}^{2+}+\mathrm{HO} \bullet+\mathrm{H}^{+} \\
\mathrm{M}+\mathrm{HO} \bullet \rightarrow \mathrm{M}_{1}+\mathrm{HO} \bullet \rightarrow \mathrm{M}_{2}+\mathrm{HO} \bullet \rightarrow \ldots . . . \rightarrow \mathrm{CO}_{2}+\mathrm{H}_{2} \mathrm{O}
\end{gathered}
$$

At the same time, $\mathrm{HO}$ suffer parallel reactions:

$$
\begin{gathered}
\mathrm{HO} \bullet+\mathrm{HO} \bullet \rightarrow \mathrm{H}_{2} \mathrm{O}_{2} \\
\mathrm{H}_{2} \mathrm{O}_{2}+\mathrm{HO} \bullet \rightarrow \mathrm{HO}_{2}^{\bullet}+\mathrm{H}_{2} \mathrm{O} \\
2 \mathrm{HO}_{2}^{\bullet} \rightarrow \mathrm{H}_{2} \mathrm{O}_{2}+\mathrm{O}_{2}
\end{gathered}
$$

Reactions from 4 to 6 are considered unproductive because these consume the $\mathrm{HO}$ at a rate higher than that of organic matter oxidation. Due to the second-order nature of (Reaction 4), if $\mathrm{HO}$ is produced at too high concentration counterproductive reactions are favored which causes the process performance to drop [2]. This poses a trade-off between not limiting the decontamination process due to a lack of $\mathrm{H}_{2} \mathrm{O}_{2}$ and not reaching $\mathrm{H}_{2} \mathrm{O}_{2}$ excess, consequently, adequately dosing $\mathrm{H}_{2} \mathrm{O}_{2}$ along the reaction span arises as an extremely difficult optimization problem that has been barely studied, which is out of the scope of this work. [3,4].

For batch operation, which is the research mainstream, a single addition of $\mathrm{H}_{2} \mathrm{O}_{2}$ at the beginning of the reaction is known to be inefficient $[5,6]$. During decades, the impact of the $\mathrm{Fe}^{2+} / \mathrm{H}_{2} \mathrm{O}_{2}$ ratio on process performance was recognized as a critical parameter [7] and was widely studied in the literature [1], nevertheless, the search for a convenient constant ratio is limiting [8]. Such a value should actually be revised according to the variable concentrations caused by process dynamics [4,9]. In this context, the sequential addition of $\mathrm{H}_{2} \mathrm{O}_{2}$ along the reaction span has been reported to enhance mineralization $[10,11]$, furthermore, continuous automatic dosage has also been studied, with positive results [12]. However, the determination of an adequate dosage cannot be limited to a pre-fixed recipe (open-loop control), but it should ideally consider some process feed-back (closed-loop control) to adapt to process disturbances and or model mismatch in a robust way [13]. It is important to stress that the $\mathrm{H}_{2} \mathrm{O}_{2}$ dosage strategy is extremely significant for photo-Fenton process competitiveness because the $\mathrm{H}_{2} \mathrm{O}_{2}$ is the most expensive reagent; consequently, reducing its consumption is key to reducing its operation cost [14].

A first-principles dynamic model mathematically describing the kinetics and evolution of the chemical species involved in this process would allow determining in advance the $\mathrm{H}_{2} \mathrm{O}_{2}$ dosage profile satisfying any given criterion. Lacking such a reliable model, a convenient $\mathrm{H}_{2} \mathrm{O}_{2}$ addition scheme is the on-line adaptation of the dosage based on inferred information about the current status of the process dynamics. This feedback mechanism requires selecting a practical, affordable and informative on-line measurement. Different variables, such as Redox potential [15], have been explored; nevertheless, dissolved oxygen (DO) has demonstrated to be efficient and useful, as well as conceptually consistent with the kinetic model (Reaction 6) [16]. Recently, it was reported that the use of the derivative of the online DO measurement allows providing a significant improvement in process performance [13]. The proposed $\mathrm{H}_{2} \mathrm{O}_{2}$ dosage methodology consists of a hybrid strategy including an initial single $\mathrm{H}_{2} \mathrm{O}_{2}$ addition (open-loop) followed by a continuous addition until an appropriate DO level is attained. Finally, $\mathrm{H}_{2} \mathrm{O}_{2}$ inflow is carried out on a simple on-off control system to keep the DO slope [13] between selected upper and lower bounds (closed-loop). Although proving the concept [13], the evidence and the assessment were limited to samples of synthetic water of a single compound at a fixed concentration (Paracetamol, PCT, $100 \mathrm{mg} \mathrm{L}^{-1}$ ), a limitation also shared by other works [8,16]. Therefore, this work addresses the generalization and improvement of such $\mathrm{H}_{2} \mathrm{O}_{2}$ dosage methodology by extending its validation to different individual pollutants as well as pollutant mixtures, different initial concentrations and different water matrixes.

While the study of the monitoring of DO as a means to provide feedback to the $\mathrm{H}_{2} \mathrm{O}_{2}$ dosage could be performed using a variety of organic compounds, Paracetamol (PCT) and Sulfamethazine (SMT) were selected because of the number of publications addressing their 
oxidation by means of the photo-Fenton process. Specifically, paracetamol (PCT) is used as a model pollutant in many previous related studies $[8,13,16]$ due to its large consumption worldwide. Seemingly, Sulfamethazine (SMT) is another pharmaceutical product derived from sulfamethoxazole included in the EU Watch List. The concentrations for PCT and SMT were selected assuming wastewaters characterized by high concentration levels of contaminants, total organic carbon (TOC), and chemical oxygen demand (COD), such as pharmaceutical or hospital wastewaters. Thus, the concentration ranges adopted for these contaminants are inspired by the works by Dalgic et al. (2017) [17], who showed that the Fenton process can be an effective pre-treatment of a real paracetamol wastewater of the pharmaceutical industry characterized by a PCT concentration between 37 and $294 \mathrm{mg} \mathrm{L}^{-1}$ and Roshanfekr Rad et al. (2015) [18], who investigated the use of the photo-Fenton process in industrial applications and addressed phenol and paracetamol concentrations ranging between 20 and $100 \mathrm{mg} \mathrm{L}^{-1}$.

Finally, the possibility of simplifying the dosage strategy by decreasing the number of recipe parameters (inputs) is finally discussed in light of the results.

\section{Materials and Methods}

\subsection{Reagents}

Paracetamol ( $98 \%$ purity), from now on PCT, and Sulfamethazine ( $99 \%$ purity), from now on SMT, were purchased from Sigma-Aldrich, while hydrogen peroxide $(33 \% w / v)$ was purchased from Panreac. The catalyst, added as heptahydrate ferrous sulphate $\left(\mathrm{FeSO}_{4} \cdot 7 \mathrm{H}_{2} \mathrm{O}\right)$, was provided by Merck. Sulfuric acid (95\%) used to adjust the $\mathrm{pH}$ was provided by Fisher. $\mathrm{H}_{2} \mathrm{O}_{2}$ was determined following the ammonium metavanadate $\left(\mathrm{NH}_{4} \mathrm{VO}_{3}\right.$ 98.5\%) which was obtained from Fisher. Distilled water (DW) was used as water matrix in most of the experiments while the assays carried out to assess water matrix effect were done in natural water (NW).

\subsection{Pilot Plant}

The pilot plant, with a total reaction volume of $15 \mathrm{~L}$, consisted of a glass tube, photoreactor (1.5 L, Table 1) and a reservoir tank (13.5 L) in which a centrifugal pump (Iwaki Magnet Pump, MD-30RZ-220, 1-16HP-220V) operated at a flow rate of $12 \mathrm{~L} \mathrm{~min}^{-1}$ was used to recirculate water assuring the complete mixing of the system.

Table 1. Photoreactor specifications.

\begin{tabular}{ccc}
\hline Irradiated volume, $\mathrm{L}$ & & 1.5 \\
Annular irradiated height, $\mathrm{mm}$ & & 130 \\
Outer cylinder & Outer diameter, $\mathrm{mm}$ & 150 \\
& Inner diameter, $\mathrm{mm}$ & 140 \\
Inner cylinder & Outer diameter, $\mathrm{mm}$ & 70 \\
& Inner diameter, $\mathrm{mm}$ & 63.6 \\
\hline
\end{tabular}

The incident photon power, $\mathrm{E}=3.36 \times 10^{-4}$ Einstein $\mathrm{min}^{-1}(300$ and $420 \mathrm{~nm})$ is provided by a Philips Actinic BL TL $36 \mathrm{~W} / 10$ 1SL lamp (UVA-UVB). This value was measured using potassium ferrioxalate actinometry. The pilot plant includes on-line measurement sensors for $\mathrm{pH}$ (Hamilton Polilyte HTVP 120), temperature and DO/DO slope (Hamilton Oxysens) monitoring. The automatic dosage of $\mathrm{H}_{2} \mathrm{O}_{2}$ is done through a peristaltic pump (Watson Marlow, OEM $31324 \mathrm{~V}$ ) controlled by a PLC program (Siemens SIMATIC S7-1200) that is managed by InTouchR ${ }^{\circledR}$ software (plant SCADA system). A complete description of the pilot plant can be found elsewhere [13].

\subsection{Analytical Methods}

The decontamination process was monitored through total organic carbon (TOC) concentration, which was measured by a TOC (TOC-VCSH/CSN Shimadzu; Kyoto, Japan) analyzer. Duplicate TOC measurements were always performed. The ammonium meta- 
vanadate spectrophotometric method developed by [19] was used to determine $\mathrm{H}_{2} \mathrm{O}_{2}$ concentration (Lambda 365 UV/Vis spectrophotometer, Perkin Elmer, United States).

\subsection{Experimental Procedure}

All the photo-Fenton experiments were done as follows: $15 \mathrm{~L}$ of the corresponding type of water were loaded in the system, afterwards, the pollutant was added. With respect to the pollutant, the following options have been assessed: (i) $100 \mathrm{mg} \mathrm{L}^{-1}$ of PCT (63 mg TOC L ${ }^{-1}$ ), (ii) $200 \mathrm{mg} \mathrm{L}^{-1}$ of PCT (126 mg L${ }^{-1}$ of TOC), (iii) $50 \mathrm{mg} \mathrm{L}^{-1}$ of PCT and $61.5 \mathrm{mg} \mathrm{L}^{-1}$ of SMT (63 mg L $\mathrm{m}^{-1}$ of TOC, where each pollutant provided half of the total TOC concentration) and (iv) $123 \mathrm{mg} \mathrm{L}^{-1}$ of SMT (63 mg L $\mathrm{mg}^{-1}$ of TOC). Then, $\mathrm{H}_{2} \mathrm{SO}_{4}$ was used to set the $\mathrm{pH}$ at 2.8 and the selected concentration of pre-dissolved catalyst was added. Recirculation was maintained for $10 \mathrm{~min}$ and the first sample was taken for initial iron and TOC measurements. Finally, the UV lamp was switched and $\mathrm{H}_{2} \mathrm{O}_{2}$ addition started simultaneously to trigger the decontamination process.

Experiments were performed based on the proposed hybrid $\mathrm{H}_{2} \mathrm{O}_{2}$ dosing strategies by Yu et al., 2021 [13], Figure 1:

I. Initial stage (open-loop): Single initial addition at the beginning of the assay. The initial $\mathrm{H}_{2} \mathrm{O}_{2}$ concentrations are selected as a percentage of the $\mathrm{H}_{2} \mathrm{O}_{2}$ stoichiometric concentration (i.e., the stoichiometric concentration for $100 \mathrm{mg} \mathrm{L}^{-1}$ of PCT is $472 \mathrm{mg} \mathrm{L}^{-1}$; for $123 \mathrm{mg} \mathrm{L}^{-1}$ of SMT it is $631 \mathrm{mg} \mathrm{L}^{-1}$ ),

II. Transition stage (close-loop): Continuous automatic addition of $\mathrm{H}_{2} \mathrm{O}_{2}$ from the beginning of the assays at a pre-fixed flow rate of $0.287 \mathrm{~mL} \mathrm{~min}^{-1}$. This addition is maintained until attaining the set $\mathrm{DO}$ level. The previously proposed DO set point is $4 \mathrm{mg} \mathrm{L}^{-1}$.

III. Final stage (closed-loop): after the transition stage, automatic $\mathrm{H}_{2} \mathrm{O}_{2}$ addition ( $0.287 \mathrm{~mL} \mathrm{~min}^{-1}$ prefixed flow rate) is based on an on-off controller depending on the DO slope value. In general, the $\mathrm{H}_{2} \mathrm{O}_{2}$ addition is turned off when the DO slope reaches a maximum threshold of $0.2 \mathrm{mg} \mathrm{L}^{-1} \mathrm{~min}^{-1}$, while it is turned on when the DO slope falls below a minimum threshold of $0.1 \mathrm{mg} \mathrm{L}^{-1} \mathrm{~min}^{-1}$.

\begin{tabular}{|c|c|c|}
\hline INITIAL STAGE (Open Loop) & TRANSITION STAGE (Closed Loop) & FINAL STAGE (Closed Loop) \\
\hline $\begin{array}{l}\text { - Single one-shot intial } \\
\text { addition }\left(\Delta V_{0}\right) \\
\text { - Set initial concentration }\left(\mathrm{C}_{0}\right)\end{array}$ & $\begin{array}{l}\text { - Continuous automatic addition } \\
\text { - Based on DO level } \\
\text { - Addition stops when a certain } \\
\text { DO level (SP1) is attained }\end{array}$ & $\begin{array}{l}\text { - } \text { On-off flow control } \\
\text { - } \text { Based on DO slope } \\
\text { - } \text { DO level below } \overline{S P_{2}}(\mathrm{ON}) \\
\text { - } \text { DO level above } \underline{S P_{2}} \text { (OFF) }\end{array}$ \\
\hline DECISION VARIABLES & DECISION VARIABLES & DECISION VARIABLES \\
\hline - Initial added volume $\left(\Delta V_{0}\right)$ & $\begin{array}{l}\text { - } \text { Flow }\left(F_{1}=d V / d t\right) \\
\text { - } \text { DO set point }\left(S P_{1}\right)\end{array}$ & $\begin{array}{l}\text { - } \text { Flow }\left(F_{2}=d V / d t\right) \\
\text { - } \text { Upper set point }\left(\overline{S P_{2}}\right) \\
\text { - } \quad \text { Lower set point }\left(S P_{2}\right)\end{array}$ \\
\hline
\end{tabular}

Figure 1. Scheme illustration of the $\mathrm{H}_{2} \mathrm{O}_{2}$ dosage scheme: Initial addition, Constant flow and On-Off control.

\subsection{Experiments Codification}

The codification in each experiment aims to allow an easy and fast understanding of the selected dosage strategy. It was used as follows:

I. Pollutant: codification starts with the information about the pollutant or pollutants mixture present in the wastewater by including the abbreviation of the compound preceded by a number that refers to its initial concentration. By way of illustration, PCT at $100 \mathrm{mg} \mathrm{L}^{-1}$ corresponds to 1PCT (63 $\mathrm{mg} \mathrm{L}^{-1}$ of TOC), SMT at $123 \mathrm{mg} \mathrm{L}^{-1}$ corresponds to $1 \mathrm{SMT}$ (63 mg L $\mathrm{m}^{-1}$ of TOC) and a mixture of SMT and PCT at $50 \%$ each corresponds to $0.5 \mathrm{SMT}+0.5 \mathrm{PCT}$ (also $63 \mathrm{mg} \mathrm{L}^{-1}$ of TOC). 
II. Initial stage: since initial additions were based on theoretical $\mathrm{H}_{2} \mathrm{O}_{2}$ stoichiometric amounts (coded as S), this information was coded accordingly. By way of illustration, an addition corresponding to $40 \%$ of the stoichiometric amount of the pollutant concentration was named $0.4 \mathrm{~S}$, which was added after the codification related to the nature and concentration of the pollutant.

III. Transition stage: the DO set point that marks the stop of the $\mathrm{H}_{2} \mathrm{O}_{2}$ continuous addition is then added to the codification. By way of illustration, an initial addition corresponding to $40 \%$ stoichiometric amount of PCT at $100 \mathrm{mg} \mathrm{L}^{-1}$ using $4 \mathrm{mg} \mathrm{L}^{-1}$ of DO as set point to stop the continuous addition was codified as 1PCT_0.4S_DO4. For special assays in which continuous addition during transition stage was never stopped the codification was CA instead of DO4. If the transition stage was not carried out, no codification was added.

IV. Final stage: the selected codification consisted in the addition of the minimum and maximum bounds of the DO slope used for the automatic start and stop of the $\mathrm{H}_{2} \mathrm{O}_{2}$ dosage. By way of illustration, an initial addition corresponding to $40 \%$ stoichiometric amount of PCT at $100 \mathrm{mg} \mathrm{L}^{-1}$ using $4 \mathrm{mg} \mathrm{L}^{-1}$ of DO as set point to stop the continuous addition and $0.2 \mathrm{mg} \mathrm{L}^{-1} \mathrm{~min}^{-1}$ and $0.1 \mathrm{mg} \mathrm{L}^{-1} \mathrm{~min}^{-1}$ as high and low DO slope thresholds of the on-off control system, respectively, was codified as 1PCT_0.4S_DO4_L0.1_H0.2.

V. Iron concentration: $20 \mathrm{mg} \mathrm{L}^{-1}$ of iron were used for most of the experiments; however, the catalyst concentration was doubled in a few assays. However, in this last case codification about iron concentration was added at the end $(2 \mathrm{Fe})$.

\section{Results}

Different sets of experiments were planned to assess the performance of the dosage strategy under different adjustments and for different substances and mixtures.

The assays are summarized in Table 2. All measurements were duplicated. The two time-series produced for each of the assays showed very high correlation $\left(R^{2}>0.99\right)$ and the TOC residuals obtained were all distributed with a mean of $0.06 \mathrm{mg} \cdot \mathrm{L}^{-1}$, a standard deviation of $1.5 \mathrm{mg} \cdot \mathrm{L}^{-1}$, a maximum value of $3.35 \mathrm{mg} \cdot \mathrm{L}^{-1}$ and a maximum variability (residual value/mean value) of $4.26 \%$. These values are within the reported accuracy ( 0.5 to $10 \mathrm{mg} \mathrm{L}^{-1}$ ) and variability (approx. 5\%) of the analytical method [20]. Once the repeatability and consistency of the measurements are confirmed, average values will be presented from here on.

Assays will be discussed in terms of various outcomes, such as the evolution of the concentration of the different species, and will be quantitatively assessed in terms of the efficiency in which the reactants are used to achieve the mineralization of the organic load (mg TOC removed per $\mathrm{mg} \mathrm{H}_{2} \mathrm{O}_{2}$ used). Another performance indicator considered along with this work is the $\mathrm{H}_{2} \mathrm{O}_{2}$ concentration in solution during the experiments, which should be ideally kept within the $50-100 \mathrm{mg} \mathrm{L}^{-1}$ range to minimize side reactions.

\subsection{Water Matrix Effect on Dosage Strategy: Distilled Water vs. Natural Water}

Water matrix constituents present a significant impact, in general, on advanced oxidation processes [21] and, particularly, on the photo-Fenton process [22]. The dosage strategy previously proposed [13] and adopted in this work was preliminarily evaluated under conditions closer to the treatment of actual industrial wastewaters by changing the water matrix from DW to NW (Figure 1). Consequently, conductivity, which is a good indicator of the water matrix inorganic content, increased from $1.5 \mu \mathrm{S} \mathrm{cm}{ }^{-2}$ to $1010 \mu \mathrm{S} \mathrm{cm}{ }^{-2}$. This is significant, since the presence of inorganic ions in solution may have a negative effect on the mineralization rate, mainly due to the complexation of the inorganic ions with iron species in solution and the scavenging of $\mathrm{HO} \bullet$, generating other less reactive radicals [23]. 
Table 2. Experimental plan.

\begin{tabular}{|c|c|c|c|c|c|c|c|c|}
\hline \multirow{2}{*}{ Assay Code } & \multirow{2}{*}{$\begin{array}{c}\text { PCT } \\
\mathrm{mg} \mathrm{L}^{-1}\end{array}$} & \multirow{2}{*}{$\begin{array}{c}\mathrm{SMT} \\
\mathrm{mg} \mathrm{L}^{-1}\end{array}$} & \multirow{2}{*}{$\begin{array}{c}\text { TOC } \\
\mathrm{mg} \mathrm{L}^{-1}\end{array}$} & \multirow{2}{*}{$\begin{array}{c}\text { Iron } \\
\text { mg L }^{-1}\end{array}$} & \multirow{2}{*}{$\begin{array}{c}\text { Initial } \mathrm{H}_{2} \mathrm{O}_{2} \\
\mathrm{mg} \mathrm{L}^{-1}\end{array}$} & \multicolumn{3}{|c|}{ Dosage Stage } \\
\hline & & & & & & Initial & Transition & Final \\
\hline 1PCT_0.4S_DO4_L0.15_H0.25_DW & 100 & 0 & 63 & 20 & 189 & YES & YES & YES \\
\hline 1PCT_0.4S_DO4_L0.15_H0.25_NW & 100 & 0 & 63 & 20 & 189 & YES & YES & YES \\
\hline 2PCT_0.25S_DO4 & 200 & 0 & 126 & 20 & 236 & YES & YES & NO \\
\hline 2PCT_0.3S_DO4 & 200 & 0 & 126 & 20 & 283 & YES & YES & NO \\
\hline 2PCT_0.4S_DO4 & 200 & 0 & 126 & 20 & 378 & YES & YES & NO \\
\hline 2PCT_0.4S_DO4_2Fe & 200 & 0 & 126 & 40 & 378 & YES & YES & NO \\
\hline 2PCT_0.3S_DO4_L0.1_H0.2 & 200 & 0 & 126 & 20 & 283 & YES & YES & YES \\
\hline 2PCT_0.4S_DO4_L0.1_H0.2 & 200 & 0 & 126 & 20 & 378 & YES & YES & YES \\
\hline 2PCT_0.4S_DO4_L0.1_H0.2_2Fe & 200 & 0 & 126 & 40 & 378 & YES & YES & YES \\
\hline 1PCT_0.4S_DO4 & 100 & 0 & 63 & 20 & 189 & YES & YES & NO \\
\hline 1SMT_0.4S_DO4 & 0 & 123 & 63 & 20 & 252 & YES & YES & NO \\
\hline 0.5PCT_0.5SMT_0.4S_DO4 & 50 & 61.5 & 63 & 20 & 221 & YES & YES & NO \\
\hline 1SMT_0.2S & 0 & 123 & 63 & 20 & 126 & YES & NO & NO \\
\hline 1SMT_0.3S_CA & 0 & 123 & 63 & 20 & 189 & YES & YES & NO \\
\hline 1SMT_0.4S & 0 & 123 & 63 & 20 & 252 & YES & NO & NO \\
\hline 1SMT_0.4S_CA & 0 & 123 & 63 & 20 & 252 & YES & YES & NO \\
\hline 1SMT_0.6S & 0 & 123 & 63 & 20 & 379 & YES & NO & NO \\
\hline 1SMT_0.8S & 0 & 123 & 63 & 20 & 505 & YES & NO & NO \\
\hline 1SMT_1.0S & 0 & 123 & 63 & 20 & 631 & YES & NO & NO \\
\hline 1SMT_0.4S_CA_L0.1_H0.2 & 0 & 123 & 63 & 20 & 252 & YES & NO & YES \\
\hline 1SMT_0.3S_CA_L0.1_H0.2 & 0 & 123 & 63 & 20 & 189 & YES & NO & YES \\
\hline 1SMT_0.4S_L0.1_H0.2 & 0 & 123 & 63 & 20 & 252 & YES & $\mathrm{NO}$ & YES \\
\hline
\end{tabular}

The results (Figure 2) obtained for the initial stage (single one-shot addition of $\mathrm{H}_{2} \mathrm{O}_{2}$ ) showed negligible differences between NW and DW experiments. For the transition stage (continuous $\mathrm{H}_{2} \mathrm{O}_{2}$ addition until DO achieving the set-up value, $4 \mathrm{mg} \mathrm{L}^{-1}$ based on previous studies [13]), the oxygen production was revealed to increase with a higher inorganic load in the water matrix, while the DO set point was reached for NW (20.5 min) 5 min earlier than for DW ( $25.5 \mathrm{~min})$. Immediately after the transition stage, the continuous addition of $\mathrm{H}_{2} \mathrm{O}_{2}$ is stopped and the automatic addition (on-off control system based on the DO slope signal) is started. The use of $0.15 \mathrm{mg} \mathrm{O}_{2} \mathrm{~L}^{-1} \mathrm{~min}^{-1}$ and $0.25 \mathrm{mg} \mathrm{O}_{2} \mathrm{~L}^{-1} \mathrm{~min}^{-1}$ as low and high set points to start and stop $\mathrm{H}_{2} \mathrm{O}_{2}$ addition, respectively, is justified based on previous results [13]. During this last stage, the resulting average $\mathrm{H}_{2} \mathrm{O}_{2}$ concentrations in the reaction bulk were $79.8 \pm 17 \mathrm{mg} \mathrm{L}^{-1}(\mathrm{DW})$ and $76.8 \pm 12 \mathrm{mg} \mathrm{L}^{-1}(\mathrm{NW})$.

\subsection{Validating the Dosage Strategy with Different Pollutant Concentrations}

Industrial wastewater characteristics are highly dependent on the type of industry; indeed, within the same type of activity, the organic load depends on the source and time. Hence, to validate the dosage strategy in front of these changes, the PCT initial concentration was increased from $100 \mathrm{mg} \mathrm{L}^{-1}$ to $200 \mathrm{mg} \mathrm{L}^{-1}$, which corresponds to a TOC increase from $63 \mathrm{mg} \mathrm{L}^{-1}$ to $126 \mathrm{mg} \mathrm{L}^{-1}$.

Double PCT initial concentration decreased the $\mathrm{H}_{2} \mathrm{O}_{2}$ concentration from $378 \mathrm{mg} \mathrm{L}^{-1}$ (0.4S, $40 \%$ of the stoichiometric concentration) to a minimum value of $118 \mathrm{mg} \mathrm{L}^{-1}$ after $15 \mathrm{~min}$ (Figure 3A. Then, $\mathrm{H}_{2} \mathrm{O}_{2}$ slowly accumulated in the reactor up to $180 \mathrm{mg} \mathrm{L}^{-1}$ after $39 \mathrm{~min}$ of reaction time, when DO reached $4 \mathrm{mg} \mathrm{L}^{-1}$. These values are above the desired concentration range, which has been ideally set between $50 \mathrm{mg} \mathrm{L}^{-1}$ and $100 \mathrm{mg} \mathrm{L}^{-1}$. 


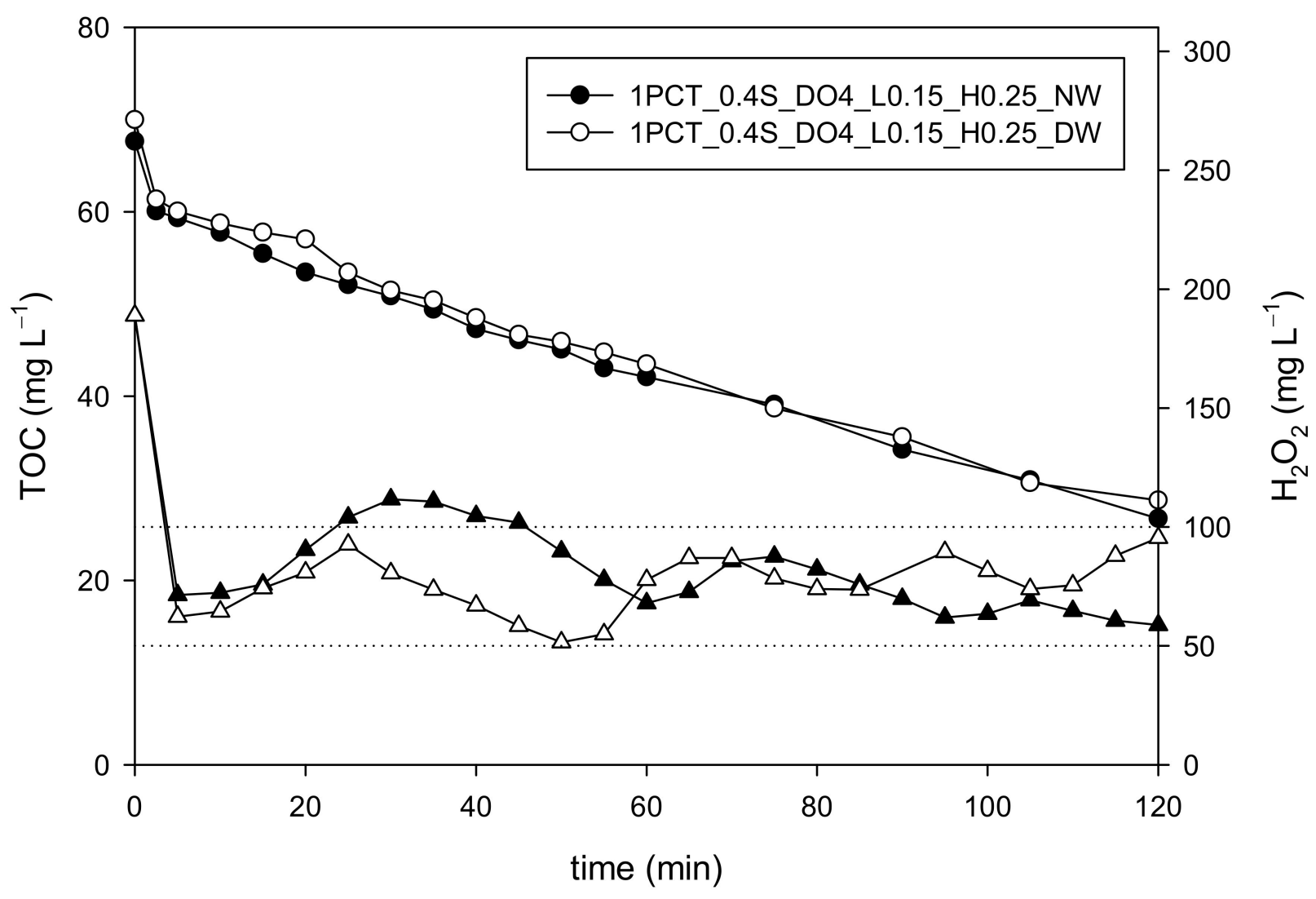

Figure 2. Comparison of TOC (round symbols) and $\mathrm{H}_{2} \mathrm{O}_{2}$ (triangular symbols) concentration profiles when the 0.4S_DO4_L0.15_H0.25 dosage strategy is applied for the treatment of $100 \mathrm{mg} \mathrm{L}^{-1}$ PCT (63 mg L ${ }^{-1}$ TOC) contaminated wastewater in NW and DW by photo-Fenton process.

In this way, the $\mathrm{H}_{2} \mathrm{O}_{2}$ concentration was beyond the $100 \mathrm{mg} \mathrm{L}^{-1}$, the value accepted in this work and the literature [14,24], during the whole assay. This suggests that the continuous addition of $\mathrm{H}_{2} \mathrm{O}_{2}$ could be stopped earlier, ideally from the beginning. It is significant that this option would involve reducing the time of the transition stage to zero, which may indicate that the transition stage could be bypassed or removed.

\subsection{Modifying the Wastewater Organic Matter Nature \\ 3.3.1. Paracetamol and Sulfamethoxazole Mixtures}

The 1PCT_0.4S_DO4 strategy tested in $100 \mathrm{mg} \mathrm{L}^{-1}$ of PCT $\left(63 \mathrm{mg}\right.$ of TOC $\left.\mathrm{L}^{-1}\right)$ was also tested in a mixture containing both PCT and SMT. The new solution was prepared so that each pollutant contributed one half $\left(31.5 \mathrm{mg} \mathrm{L}^{-1}\right)$ of the TOC concentration (i.e., $50 \mathrm{mg} \mathrm{L}^{-1}$ of PCT and $61.5 \mathrm{mg} \mathrm{L}^{-1}$ of SMT). The corresponding assay is coded 0.5PCT_0.5SMT_0.4S_DO4 and it was compared with 1PCT_0.4S_DO4 and SMT_0.4_DO4 assays.

The results for this new assay showed that $\mathrm{H}_{2} \mathrm{O}_{2}$ concentration decreased from $220 \mathrm{mg} \mathrm{L}^{-1}$ to $88 \mathrm{mg} \mathrm{L}^{-1}$ in $10 \mathrm{~min}$. Then, it increased up to $\approx 100 \mathrm{mg} \mathrm{L}^{-1}$ until DO reached $4 \mathrm{mg} \mathrm{L}^{-1}$ after $19 \mathrm{~min}$ (Figure 4). Therefore, the 0.4S_DO4 strategy was once again validated. Due to the interesting results regarding the use of DO slope as set point for the transition stage obtained in previous sections, the evolution of $\mathrm{H}_{2} \mathrm{O}_{2}$ concentration with respect to this variable was then monitored. When the DO slope reached $0.2 \mathrm{mg} \mathrm{L}^{-1} \mathrm{~min}^{-1}$ (11 min), the $\mathrm{H}_{2} \mathrm{O}_{2}$ concentration was $90 \mathrm{mg} \mathrm{L}^{-1}$, highlighting once again that this variable could be an interesting alternative to $\mathrm{DO}$ also for the transition stage. 

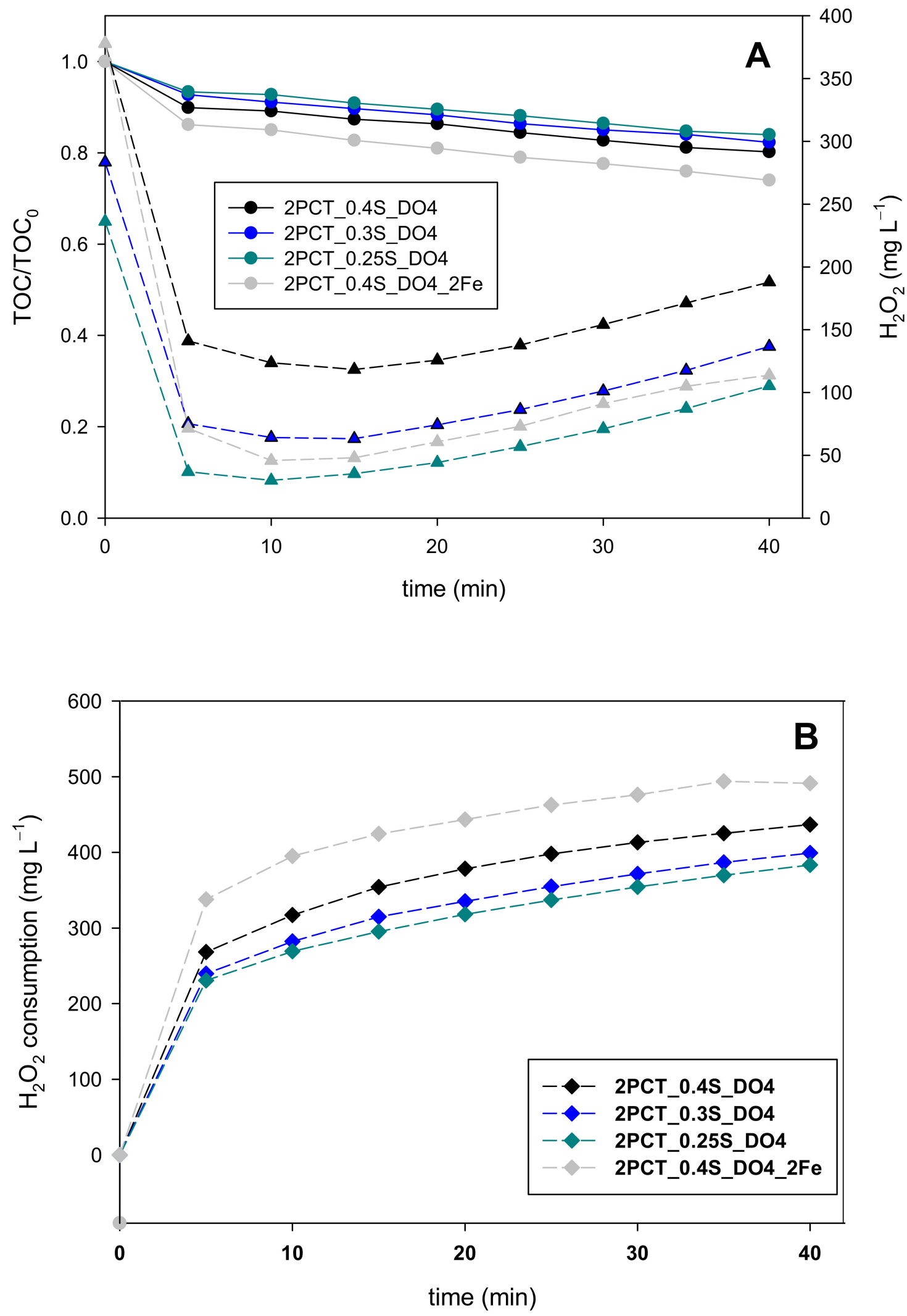

Figure 3. TOC and $\mathrm{H}_{2} \mathrm{O}_{2}$ concentration profiles—round and triangular symbols, respectively-(A) and $\mathrm{H}_{2} \mathrm{O}_{2}$ consumption curves (B) obtained using 2PCT_0.25S_DO4, 2PCT_0.3S_DO4, and 2PCT_0.4S_DO4 dosage strategies, including an additional assay doubling the iron concentration (2PCT_0.4S_DO4_2Fe). 


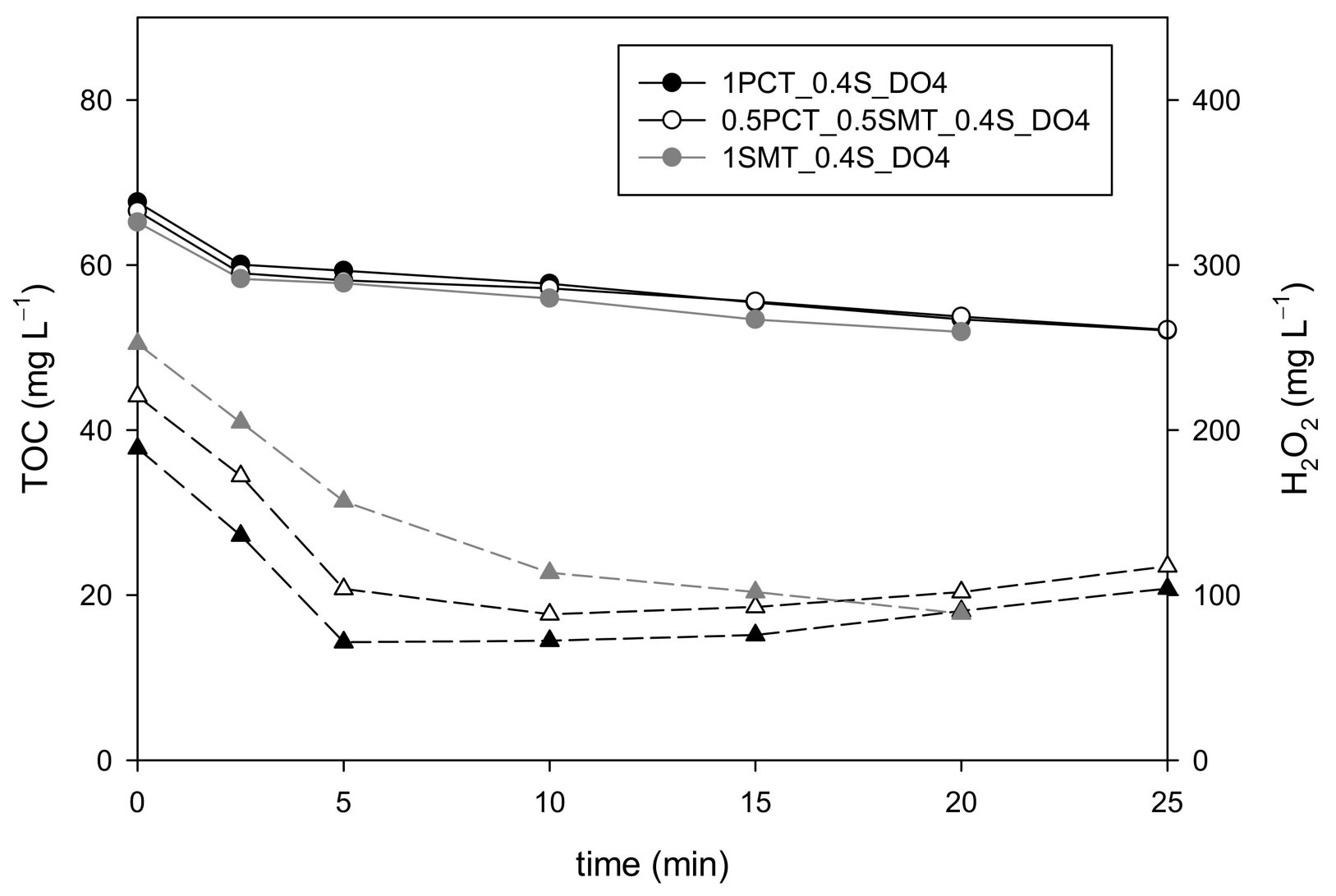

Figure 4. TOC (round symbols) and $\mathrm{H}_{2} \mathrm{O}_{2}$ (triangular symbols) concentration curves obtained with the 0.4S_DO4 dosage strategy when treating a 0.5PCT_0.5SMT mixture $\left(63 \mathrm{mg}\right.$ of TOC $\left.\mathrm{L}^{-1}\right)$.

\subsubsection{Sulfamethazine Contaminated Wastewater}

The next set of assays was performed using only SMT (63 mg of TOC $\left.\mathrm{L}^{-1}\right)$, for which the three stages of the $\mathrm{H}_{2} \mathrm{O}_{2}$ dosage strategy were completely re-evaluated.

The process performance under different one-shot initial additions from $0.2 \mathrm{~S}$ to $1 \mathrm{~S}$ (126 mg L $\mathrm{mg}^{-1}-631 \mathrm{mg} \mathrm{L}^{-1}$ ) was first evaluated (Figure 5A). Only the 1SMT_0.2S experiment presented a lower TOC reduction rate $\left(\mathrm{mg} \mathrm{L}^{-1} \mathrm{~min}^{-1}\right)$ than the rest of assays, which showed equivalent values. With respect to the $\mathrm{H}_{2} \mathrm{O}_{2}$ consumption (Figure $5 \mathrm{~B}$ ), it increased with the amount of the initial addition. While $176 \mathrm{mg} \mathrm{L}^{-1}$ were consumed in the 1SMT_0.4S assay after $10 \mathrm{~min}$, this value increased up to $208 \mathrm{mg} \mathrm{L}^{-1}$ for the 1SMT_1S assay. In addition, the $\mathrm{H}_{2} \mathrm{O}_{2}$ concentration in the reaction bulk after $10 \mathrm{~min}$ for the 1SMT_0.4S assay was 71 $\mathrm{mg} \mathrm{L}{ }^{-1}$, in the middle of the desired range to minimize side reactions, whilst the $\mathrm{H}_{2} \mathrm{O}_{2}$ concentration after $10 \mathrm{~min}$ for the rest of the experiments was above $250 \mathrm{mg} \mathrm{L}^{-1}$. Thus, the 1SMT_0.4S $\left(252 \mathrm{mg} \mathrm{L}^{-1}\right)$ option resulted in the best alternative.

The transition stage involves the continuous addition of $\mathrm{H}_{2} \mathrm{O}_{2}$ from the beginning of the treatment, and this somehow also influences the initial stage, therefore, the 1SMT_0.4S approach was then compared to $0.4 \mathrm{~S}$ and $0.3 \mathrm{~S}$ one-shot initial additions followed by continuous addition from the beginning of the assay (codified as 1SMT_0.4S_CA and 1SMT_0.3S_CA, respectively). There were no significant differences between the different strategies up to $10 \mathrm{~min}$ of reaction time, hence, all three options were evaluated for the transition stage, including the 1SMT_0.4S one-shot initial addition without further continuous addition. 

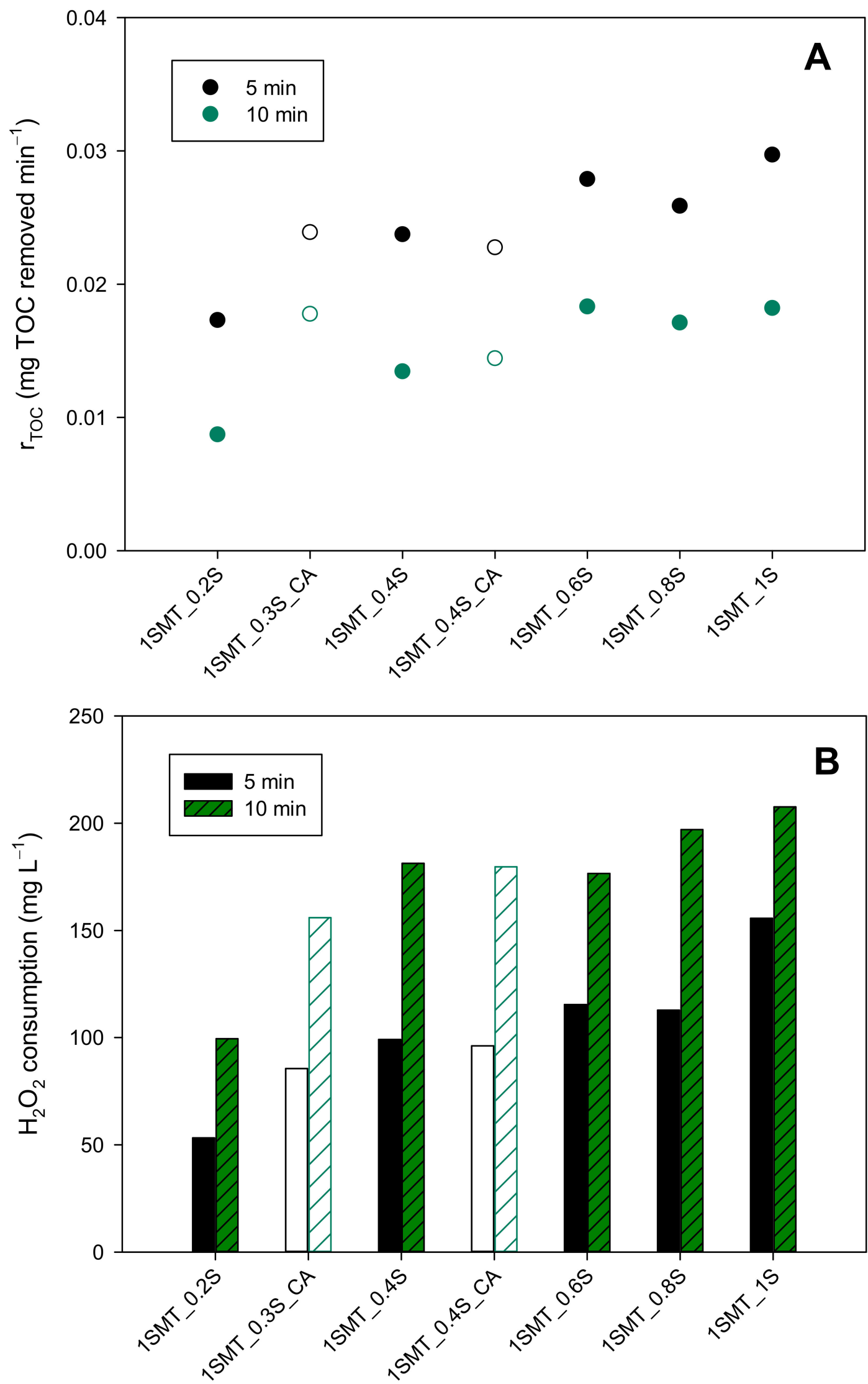

Figure 5. Mineralization rates (A) and $\mathrm{H}_{2} \mathrm{O}_{2}$ consumption (B) after 5 and $10 \mathrm{~min}$ of reaction time obtained for the treatment of SMT contaminated water under different initial $\mathrm{H}_{2} \mathrm{O}_{2}$ addition profiles (closed symbols: one-shot additions, open symbols: one-shot addition + continuous addition). 
During the transition stage, the mineralization rates were the same independently of the selected strategy up to the moment in which each assay reached the DO set point (4 mg L ${ }^{-1}$ ). In this way, the $\mathrm{H}_{2} \mathrm{O}_{2}$ evolution and consumption were the variables compared to determine the feasibility of the different alternatives. Figure 6 shows that the $\mathrm{H}_{2} \mathrm{O}_{2}$ consumption was equivalent up to $20 \mathrm{~min}$ for the 1SMT_0.4S and 1SMT_0.3S_CA experiments. Moreover, the $\mathrm{H}_{2} \mathrm{O}_{2}$ concentration in the reaction bulk after $10 \mathrm{~min}$ was quite similar and within the objective range in both cases, 71 and $86 \mathrm{mg} \mathrm{L}^{-1}$, respectively. Regarding the 1SMT_0.4S_CA strategy, there was a moderate increase of $\mathrm{H}_{2} \mathrm{O}_{2}$ consumption with respect to the other two options after $10 \mathrm{~min}$. This is in accordance with its $\mathrm{H}_{2} \mathrm{O}_{2}$ evolution profile because the concentration of this reagent in the system remained above $135 \mathrm{mg} \mathrm{L}^{-1}$ from 10 to $20 \mathrm{~min}$ favoring the proliferation of side reactions. Consequently, the 1SMT_0.4S and the 1SMT_0.3S_CA dosage strategies presented a more adequate performance than the 1SMT_0.4S_CA strategy.

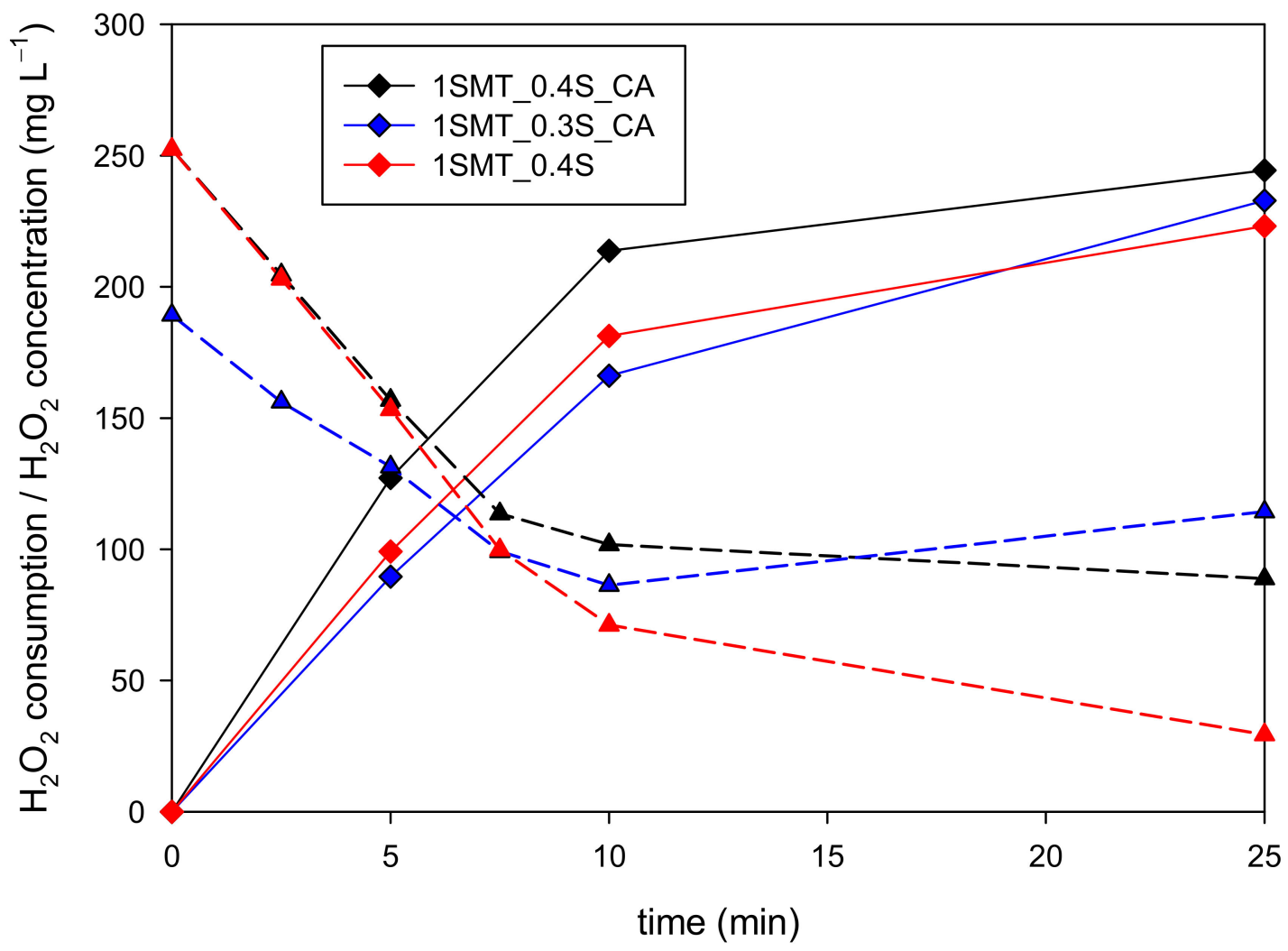

Figure 6. Comparison of $\mathrm{H}_{2} \mathrm{O}_{2}$ consumptions (continuous lines) and concentration (dashed lines) profiles obtained with the 1SMT_0.4S_CA,SMT_0.3S_CA and 1SMT_0.4S dosage strategies during the transition stage of SMT contaminated water treatment.

The information provided by the DO and DO slope signals was suitable in both cases, but again more precise for the latter (Figure 7). By way of illustration, in the 1SMT_0.3S_CA experiment, the $4 \mathrm{mg} \mathrm{L}^{-1} \mathrm{DO}$ set point was reached in $19 \mathrm{~min}$, while the DO slope reached $0.2 \mathrm{mg} \mathrm{L}^{-1} \mathrm{~min}^{-1}$ in $12 \mathrm{~min}$. Since the $\mathrm{H}_{2} \mathrm{O}_{2}$ concentration started to accumulate in the system from $86 \mathrm{mg} \mathrm{L}^{-1}$ at $\min 10$ to $>100 \mathrm{mg} \mathrm{L}^{-1}$ at $\min 20$, to stop the continuous addition at $12 \mathrm{~min}$ is a more adequate response, even though $19 \mathrm{~min}$ is a perfectly acceptable stop time. Very similar conclusions were obtained for the rest of $\mathrm{H}_{2} \mathrm{O}_{2}$ dosage strategies; consequently, all the data obtained along this work suggest that DO slope provides more accurate information about $\mathrm{H}_{2} \mathrm{O}_{2}$ evolution than DO during the transition stage. Furthermore, the same values that have been previously used as set points for the on-off control system during the final automatic dosage stage provide the right information to stop/start the continuous addition and to mark the automatic dosage kick 
off. Notice that $0.1 \mathrm{mg} \mathrm{L}^{-1}$ of DO slope would mark the start of the $\mathrm{H}_{2} \mathrm{O}_{2}$ addition in the 1SMT_0.4S_DO4 experiment because there is no continuous addition. Thus, to integrate the transition stage and the automatic stage seems the logical option because both phases can be based on the same control variable and set points. This means a new step forward in the search for a simple and generalized $\mathrm{H}_{2} \mathrm{O}_{2}$ dosage strategy.

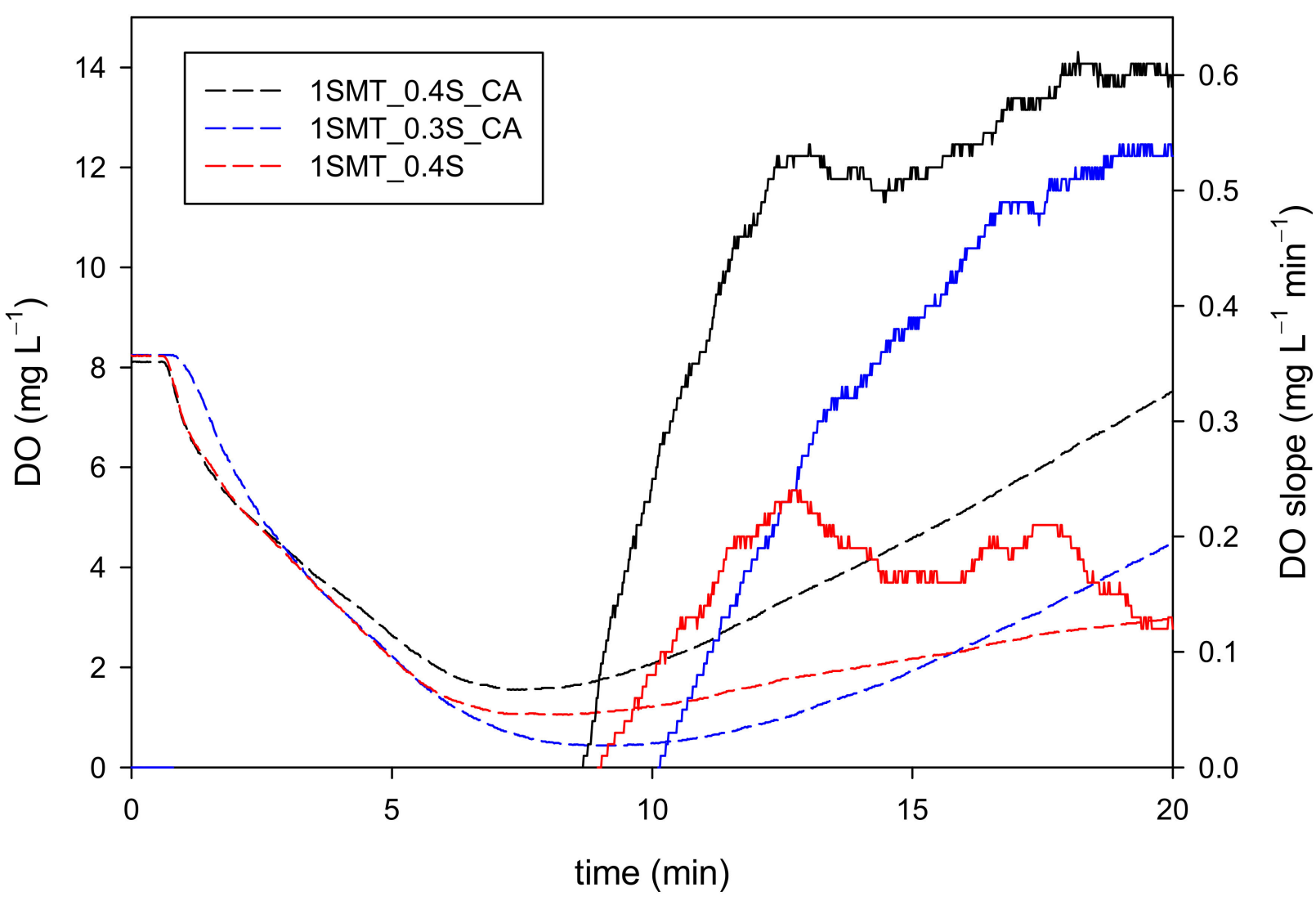

Figure 7. DO (dashed lines) and DO slope (lines) evolution profiles during the transition stage of SMT contaminated water treatment using 1SMT_0.4S_CA, 1SMT_0.3S_CA and 1SMT_0.4S dosage strategies.

In this context, the last set of experiments (codification presented in Table 2) was focused on the direct coupling of the selected initial dosage strategies with the on-off control system using $0.1 \mathrm{mg} \mathrm{L}^{-1} \mathrm{~min}^{-1}$ and $0.2 \mathrm{mg} \mathrm{L}^{-1} \mathrm{~min}^{-1} \mathrm{DO}$ slope values as set points, as explained in previous sections (1SMT_0.4S_L0.1_H0.2, 1SMT_0.3S_CA_L0.1_H0.2 and 1SMT_0.4S_CA_L0.1_H0.2). Although some small differences between the assays can be observed (Figure 8), the results of all three options were suitable with nearly equivalent efficiencies. The 0.4S_L0.1_H0.2 strategy showed a slightly lower mineralization rate $(0.25 \mathrm{mg}$ of TOC removed $\mathrm{min}^{-1}$ ) than the other two experiments, but also a lower $\mathrm{H}_{2} \mathrm{O}_{2}$ consumption $\left(416 \mathrm{mg} \mathrm{L}^{-1}\right)$. The opposite situation was found in the 1SMT_0.3S_CA_L0.1_H0.2 and 1SMT_0.4S_CA_L0.1_H0.2 assays, as the mineralization rates were slightly higher ( 0.27 and $0.26 \mathrm{mg}$ of TOC removed $\mathrm{min}^{-1}$, respectively) but the $\mathrm{H}_{2} \mathrm{O}_{2}$ consumptions were also higher (458 and $480 \mathrm{mg} \mathrm{L}^{-1}$, respectively). The average $\mathrm{H}_{2} \mathrm{O}_{2}$ concentrations in the system from $15 \mathrm{~min}$ to $120 \mathrm{~min}$ were $52 \pm 8 \mathrm{mg} \mathrm{L}^{-1}, 58 \pm 9 \mathrm{mg} \mathrm{L}^{-1}$ and $66 \pm 15 \mathrm{mg} \mathrm{L}^{-1}$ for the 1SMT_0.4S_L0.1_H0.2, 1SMT_0.3S_CA_L0.1_H0.2 and 1SMT_0.4S_CA_L0.1_H0.2 assays, respectively. This indicates the ability of the control system for maintaining the $\mathrm{H}_{2} \mathrm{O}_{2}$ concentration within the desired range using only the DO slope as control variable and under different dosage strategies. 

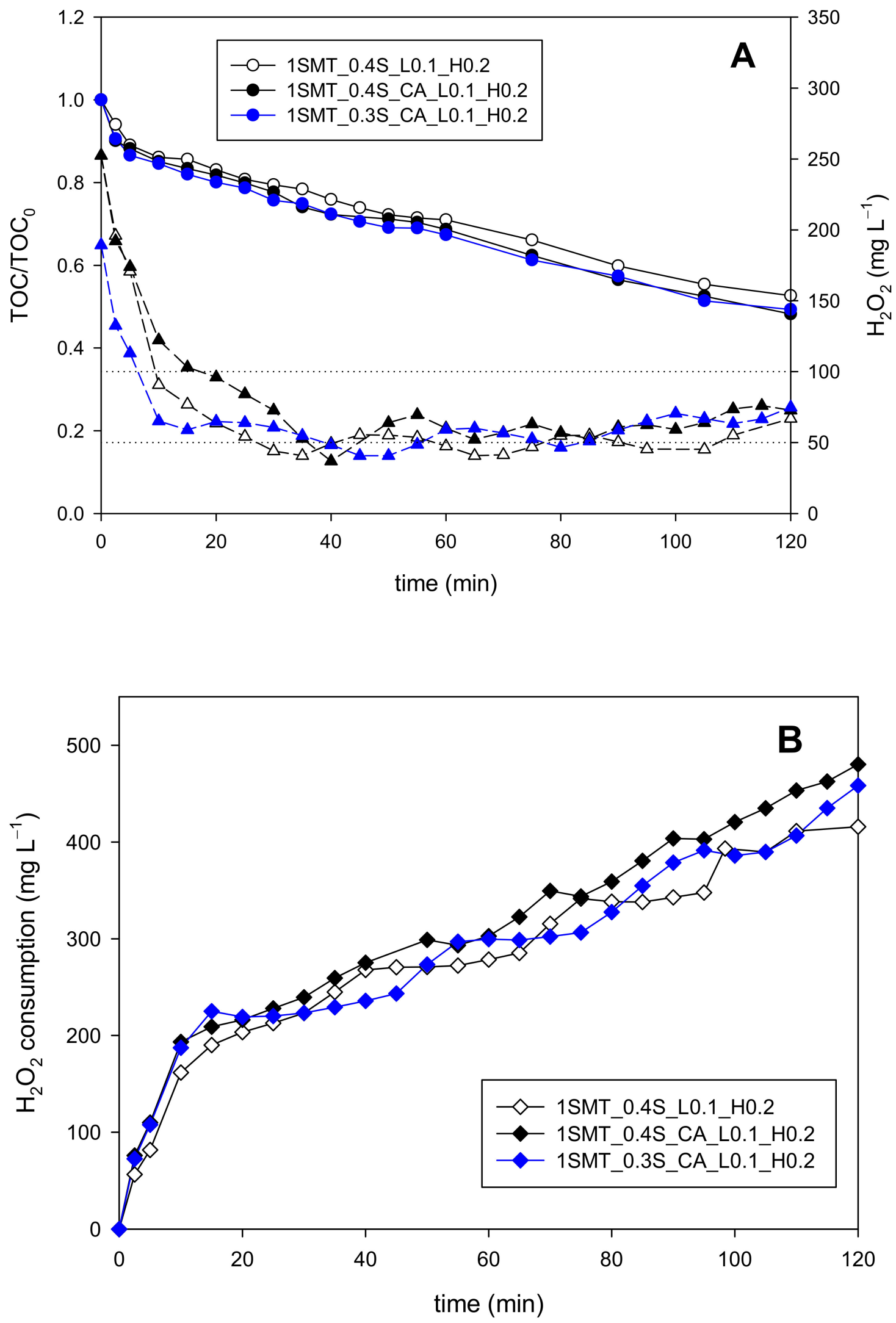

Figure 8. Mineralization (round symbols) and $\mathrm{H}_{2} \mathrm{O}_{2}$ (triangular symbols) evolution (A) and $\mathrm{H}_{2} \mathrm{O}_{2}$ consumption profiles (B) obtained with the 1SMT_0.4S_L0.1_H0.2,1SMT_0.3S_CA_L0.1_H0.2 and 1SMT_0.4S_CA_L0.1_H0.2 strategies. 


\section{Discussion}

The discussion section discusses the interpretation of these results in regard of possible justification mechanisms and the implications in regard to the selection of an efficient control strategy for the dosage of hydrogen peroxide.

\subsection{Water Matrix Effect on Dosage Strategy: Distilled Water vs. Natural Water}

The results revealed that the most adequate initial addition is the same for both water matrixes, NW and DW, concretely $40 \%$ of the theoretical stoichiometric concentration (denoted as $0.4 \mathrm{~S}$ ), since this was the minimum concentration that allowed obtaining the highest mineralization rate. Increasing the $\mathrm{H}_{2} \mathrm{O}_{2}$ initial addition above $0.4 \mathrm{~S}$ did not improve the mineralization rate.

On the other hand, the initial oxygen consumption can be explained by the Dorfman reaction, which generates less reactive oxygen species (ROS) [16,23]. Probably, the Dorfman mechanism is boosted by the higher amount of ROS participating in the reaction mechanisms due to the higher inorganic load; thus, oxygen can be recovered earlier.

During the on-off control stage, the average $\mathrm{H}_{2} \mathrm{O}_{2}$ concentrations in the reaction bulk obtained were $\left(79.8 \pm 17 \mathrm{mg} \mathrm{L}^{-1}\right.$ and $76.8 \pm 12 \mathrm{mg} \mathrm{L}^{-1}$ for DW and NW, respectively, being both values practically equivalent and within the range (50-100 $\left.\mathrm{m} \mathrm{L}^{-1}\right)$ that allows minimizing the side reactions unrelated to organic matter mineralization [25].

The final $\mathrm{H}_{2} \mathrm{O}_{2}$ consumptions were $464 \mathrm{mg} \mathrm{L}^{-1}$ and $482 \mathrm{mg} \mathrm{L}^{-1}$ for DW and NW, respectively. These results indicate again that the inorganic components of the water matrix may be responsible for the slight increase of the oxidant agent consumption. The comparison between the DW and NW complete experiments presented in Figure 2 reveals that the proposed dosage strategy perfectly suits the new water matrix characteristics, which means a step forward in looking for a generalized $\mathrm{H}_{2} \mathrm{O}_{2}$ dosage solution. Obviously, further actions are still needed, and future studies should consider the treatment of simulated and/or actual industrial wastewaters. In any case, based on these results, a fine tuning of the dosage strategy will probably be enough to further reduce $\mathrm{H}_{2} \mathrm{O}_{2}$ consumption.

\subsection{Validating the Dosage Strategy with Different Pollutant Concentrations}

The drawbacks of the $\mathrm{H}_{2} \mathrm{O}_{2}$ dosage strategy arise from an excess of $\mathrm{H}_{2} \mathrm{O}_{2}$ on the initial load and/or the subsequent continuous addition, which causes $\mathrm{H}_{2} \mathrm{O}_{2}$ concentration to fall outside the desired concentration range favoring oxygen production instead of organic matter degradation. This is exactly what happened in the experiments in which the initial PCT concentration was increased. Since the reference dosage strategy (0.4S_DO4_L0.1_H0.2) considers the $\mathrm{H}_{2} \mathrm{O}_{2}$ initial addition as a function of the stoichiometric concentration, increasing the pollutant concentration resulted in $\mathrm{H}_{2} \mathrm{O}_{2}$ excess in the reaction bulk. In this context, the main factor determining the initial $\mathrm{H}_{2} \mathrm{O}_{2}$ consumption is the Fenton reaction, which involves the reaction between iron and $\mathrm{H}_{2} \mathrm{O}_{2}$. This is the reason why two new alternatives were evaluated: (i) to reduce the initial one-shot addition of $\mathrm{H}_{2} \mathrm{O}_{2}$, and (ii) to increase the iron concentration.

Regarding the first option, the results of the 2PCT_0.3S_DO4 and 2PCT_0.25S_DO4 dosage strategies (find complete description in Table 2) allow for the comparing and evaluating of the modification of the initial one-shot addition (Figure 3), revealing that mineralization and $\mathrm{H}_{2} \mathrm{O}_{2}$ consumption (Figure $3 \mathrm{~B}$ ) are slightly increased with the amount of the initial addition. As previously stated, the $\mathrm{H}_{2} \mathrm{O}_{2}$ concentration is always above $100 \mathrm{mg} \mathrm{L}^{-1}$ when selecting the 0.4S_DO4 strategy and, although the mineralization rate is high, the more the $\mathrm{H}_{2} \mathrm{O}_{2}$ concentration deviates above the proposed concentration range (50-100 mg L ${ }^{-1}$ ) the more the inefficient consumption of $\mathrm{H}_{2} \mathrm{O}_{2}$ is favored due to the propagation of side reactions that result in dissolved oxygen concentration increase. The opposite situation is found for the 2PCT_0.25S_DO4 alternative. In this case, the $\mathrm{H}_{2} \mathrm{O}_{2}$ concentration after $5 \mathrm{~min}$ of reaction time decreased to $30 \mathrm{mg} \mathrm{L}^{-1}$, which falls below the lower limit of the desired range. This agrees with a reduction of the mineralization rate. The fact that the 2PCT_0.3S_DO4 strategy was the most adequate option may be justified 
because it balances the mineralization rate with respect to the total $\mathrm{H}_{2} \mathrm{O}_{2}$ addition. In any case, all three experiments presented similar efficiencies (mg of TOC removed per mg of $\mathrm{H}_{2} \mathrm{O}_{2}$ consumed) despite the differences found in the $\mathrm{H}_{2} \mathrm{O}_{2}$ concentration evolution during the experiments (Table 3).

Table 3. Information for each dosage strategy studied about $\mathrm{H}_{2} \mathrm{O}_{2}$ addition/evolution, reaction time and efficiency needed to reach the proposed set points when PCT concentration was doubled up to $126 \mathrm{mg} \mathrm{L}^{-1} \mathrm{TOC}$.

\begin{tabular}{|c|c|c|c|c|c|}
\hline & & \multicolumn{4}{|c|}{ Dosage Strategy } \\
\hline & & 2PCT_0.25S_DO4 & 2PCT_0.3S_DO4 & 2PCT_0.4S_DO4 & 2PCT_0.4S_DO4_2Fe \\
\hline \multicolumn{2}{|c|}{ Initial $\mathrm{H}_{2} \mathrm{O}_{2}$ concentration $\left(\mathrm{mg} \mathrm{L}^{-1}\right)$} & 236 & 283 & 377 & 377 \\
\hline \multicolumn{2}{|c|}{ Minimum $\mathrm{H}_{2} \mathrm{O}_{2}$ concentration in reaction bulk $\left(\mathrm{mg} \mathrm{L}^{-1}\right)$} & 30 & 63 & 118 & 46 \\
\hline \multirow{4}{*}{$\begin{array}{l}\text { DO set point } \\
\left(4 \mathrm{mg} \mathrm{L}^{-1}\right)\end{array}$} & time (min) & 55 & 47 & 39 & 36 \\
\hline & $\begin{array}{c}\text { Equivalent } * \mathrm{H}_{2} \mathrm{O}_{2} \\
\text { concentration }\left(\mathrm{mg} \mathrm{L}^{-1}\right)\end{array}$ & 583 & 580 & 623 & 604 \\
\hline & $\begin{array}{c}\text { Actual } \mathrm{H}_{2} \mathrm{O}_{2} \\
\text { concentration }\left(\mathrm{mg} \mathrm{L}^{-1}\right)\end{array}$ & 169 & 159 & 184 & 106 \\
\hline & $\begin{array}{l}\text { Efficiency (mg TOC mg } \\
\left.\mathrm{H}_{2} \mathrm{O}_{2}^{-1}\right)\end{array}$ & 0.06 & 0.06 & 0.06 & 0.06 \\
\hline \multirow{4}{*}{$\begin{array}{l}\text { DO slope set point } \\
\left(0.2 \mathrm{mg} \mathrm{L}^{-1} \mathrm{~min}^{-1}\right)\end{array}$} & time (min) & 47 & 34 & 31 & 26 \\
\hline & $\begin{array}{c}\text { Equivalent } * \mathrm{H}_{2} \mathrm{O}_{2} \\
\text { concentration }\left(\mathrm{mg} \mathrm{L}^{-1}\right)\end{array}$ & 533 & 498 & 573 & 541 \\
\hline & $\begin{array}{c}\text { Actual } \mathrm{H}_{2} \mathrm{O}_{2} \\
\text { concentration }\left(\mathrm{mg} \mathrm{L}^{-1}\right)\end{array}$ & 125 & 114 & 157 & 75 \\
\hline & $\begin{array}{l}\text { Efficiency }(\mathrm{mg} \text { TOC } \mathrm{mg} \\
\left.\qquad \mathrm{H}_{2} \mathrm{O}_{2}^{-1}\right)\end{array}$ & 0.06 & 0.05 & 0.06 & 0.06 \\
\hline
\end{tabular}

* The equivalent concentration is defined as the one that would result from the addition of the same amount of $\mathrm{H}_{2} \mathrm{O}_{2}$ to a non-reacting system (no consumption of $\mathrm{H}_{2} \mathrm{O}_{2}$ ).

Consequently, small deviations during a short time (a few minutes) can be assumed not to significantly affect the process efficiency. These results have shown that $40 \%$ of the $\mathrm{H}_{2} \mathrm{O}_{2}$ stoichiometric amount seems a good initial guess, although the value is subject to tuning, especially for highly contaminated wastewaters. Adjusting this value should consider that the $\mathrm{H}_{2} \mathrm{O}_{2}$ concentration during the first minutes (mainly driven by Fenton reaction) should already be within the $50-100 \mathrm{mg} \mathrm{L}^{-1}$ range.

Interestingly, the comparison of the results of these three assays (Table 3) reveals that the DO slope, proposed to be used only for the final stage of the dosage strategy, could also be selected as the control variable at the transition stage. For instance, using the DO slope high threshold of the on-off control system $\left(0.2 \mathrm{mg} \mathrm{L}^{-1} \mathrm{~min}^{-1}\right)$ would allow stopping the dosage of the transition stage after $31 \mathrm{~min}$ in the 2PCT_0.4S_DO4 assay, about 8 min earlier than when using $4 \mathrm{mg} \mathrm{L}^{-1}$ of DO as set up. The same efficiency would be obtained $(0.06 \mathrm{mg}$ TOC $\mathrm{mg} \mathrm{H}_{2} \mathrm{O}_{2}{ }^{-1}$ ) with less time (20\% approx.) and lower $\mathrm{H}_{2} \mathrm{O}_{2}$ consumption ( $8 \%$ approx.). Therefore, it is worth noting that adopting the DO slope signal $\left(0.2 \mathrm{mg} \mathrm{L}^{-1} \mathrm{~min}^{-1}\right)$ instead of DO as the control variable in the transition stage allows for the improving of the process performance, even though selecting $4 \mathrm{mg} \mathrm{L}^{-1}$ of DO still provides an acceptable response.

Regarding the other alternative, the iron concentration was increased proportionally to the initial pollutant concentration, i.e., iron was doubled from $20 \mathrm{mg} \mathrm{L}^{-1}$ to $40 \mathrm{mg} \mathrm{L}^{-1}$ (2PCT_0.4S_DO4_2Fe). Obviously, increasing iron concentration increases $\mathrm{H}_{2} \mathrm{O}_{2}$ consumption, which results in the higher production of radicals. However, the results obtained need further rationalization. Increasing iron concentration should be carefully balanced against the possibility of radiation becoming limiting. In this case, the theoretical limit for the iron concentration in the photo-reactor is $40 \mathrm{mg} \mathrm{L}^{-1}$ [26] and higher concentrations would have no further effect on the process outcome during the illuminated phase of the treatment. The key point is to find out if this theoretical higher availability of radicals due to the higher iron concentration is translated into organic matter oxidation reactions. 
Figure 3 again reveals that mineralization was improved with respect to the previously described experiments. Thus, the $\mathrm{H}_{2} \mathrm{O}_{2}$ concentration in the reaction bulk could be kept within the $50-100 \mathrm{mg} \mathrm{L}^{-1}$ range from $5 \mathrm{~min}$ of reaction time up to the moment in which the DO set point was reached. This option was also validated with an intermediate concentration of PCT (1.5PCT, i.e., $150 \mathrm{mg} \mathrm{L}^{-1}$ of the compound equivalent to $95 \mathrm{mg} \mathrm{L}^{-1}$ of TOC), with identical results to the ones described in this section (data not shown). The results also showed that both the $4 \mathrm{mg} \mathrm{L}^{-1} \mathrm{DO}$ and the $0.2 \mathrm{mg} \mathrm{L}^{-1} \mathrm{~min}^{-1} \mathrm{DO}$ slope set points could be selected as control signals for the transition stage. In terms of efficiency, increasing the iron concentration presented values equivalent to those obtained for the initial dosage modification alternative (Table 3).

Finally, three assays considering the complete dosage strategy (all three steps) can be similarly compared: 2PCT_0.4S_DO4_L0.1_H0.2, 2PCT_0.3S_DO4_L0.1_H0.2 and 2PCT_0.4S_DO4_L0.1_H0.2_2Fe (codification presented in Table 2). The results (Figure 9) reveal that preserving the iron to contaminant ratio allows keeping $\mathrm{H}_{2} \mathrm{O}_{2}$ concentration much closer to the desired range $50-100 \mathrm{mg} \mathrm{L}^{-1}$ than the rest of alternatives. As expected, the $\mathrm{H}_{2} \mathrm{O}_{2}$ concentration in the 2PCT_0.4S_DO4_L0.1_H0.2 experiment deviated from the desired range from the beginning of the assay. The main deviation in the 2PCT_0.3S_DO4_L0.1_H0.2 experiment was an accumulation of $\mathrm{H}_{2} \mathrm{O}_{2}$ when the on-off control system was applied, which means that the $\mathrm{DO}$ slope thresholds need to be tuned for their adaption to the new wastewater characteristics. Notice that the initial $\mathrm{H}_{2} \mathrm{O}_{2}$ addition was already modified with respect to the base strategy.

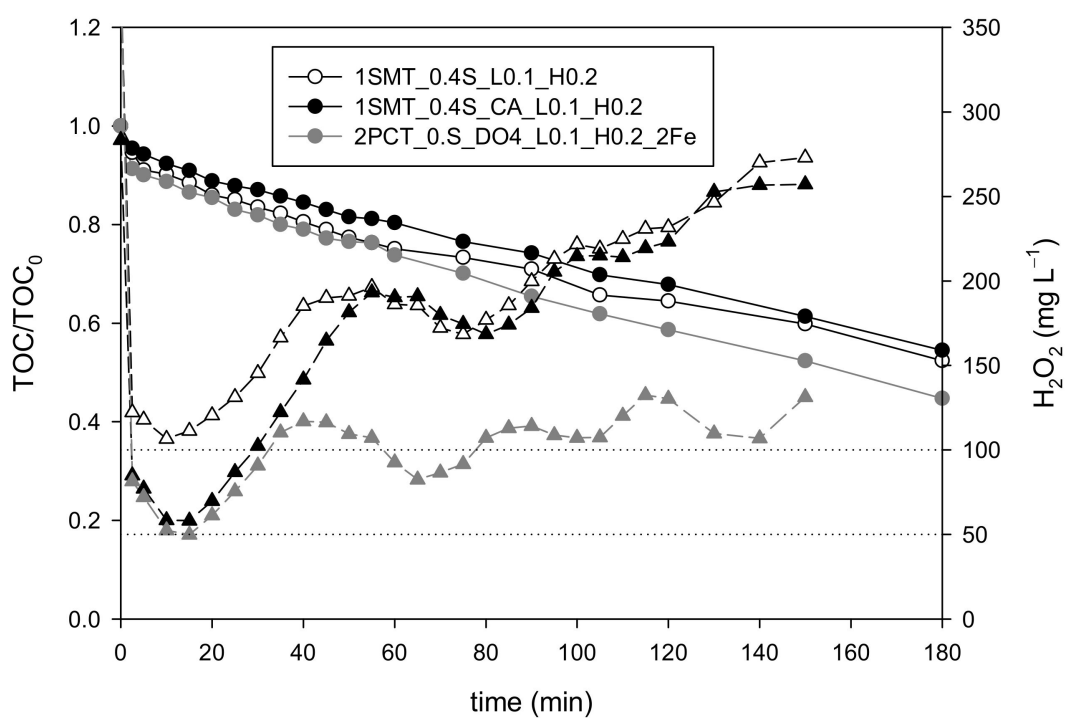

Figure 9. Comparison of different complete $\mathrm{H}_{2} \mathrm{O}_{2}$ dosage strategies for the treatment of 2PCT contaminated wastewater ( $126 \mathrm{mg} \mathrm{L}^{-1} \mathrm{TOC}$ ) by photo-Fenton process (TOC and $\mathrm{H}_{2} \mathrm{O}_{2}$ concentration profiles are represented by round and triangular symbols, respectively).

If the results of sulfamethazine contaminated wastewater are translated into efficiencies, then the 1SMT_0.4S_L0.1_H0.2 and 1SMT_0.3S_CA_L0.1_H0.2 dosage strategies (Table 2) present the highest values, 0.72 and $0.71 \mathrm{mg}$ of TOC removed per $\mathrm{mg}$ of $\mathrm{H}_{2} \mathrm{O}_{2}$ consumed, respectively, followed closely by the 1SMT_0.4S_CA_L0.1_H0.2 assay that exhibited $0.67 \mathrm{mg}$ of TOC removed per $\mathrm{mg}$ of $\mathrm{H}_{2} \mathrm{O}_{2}$ consumed. In any case, as shown in Figure 10, these values represent $25-35 \%$ improvement with respect to the efficiency obtained in the $1 \mathrm{~S}$ assay (one-shot initial addition of the theoretical stoichiometric concentration) validating the simplified dosage strategies. This involves a significant reduction of treatment cost. By way of illustration, considering the daily treatment of $100 \mathrm{~m}^{3}$ of polluted water and $0.5 € / \mathrm{kg}$ as the $\mathrm{H}_{2} \mathrm{O}_{2}$ unitary price [27], $\approx 3500 €$ annually in operating costs could be saved by implementing the 0.4S_CA_L0.1_H0.2 dosage strategy with respect to the single addition strategy. Furthermore, the implementation of controlled additions of $\mathrm{H}_{2} \mathrm{O}_{2}$ represents a 
substantial step forward for process automation, which is obviously a critical factor for the photo-Fenton process achieving full-scale applications.

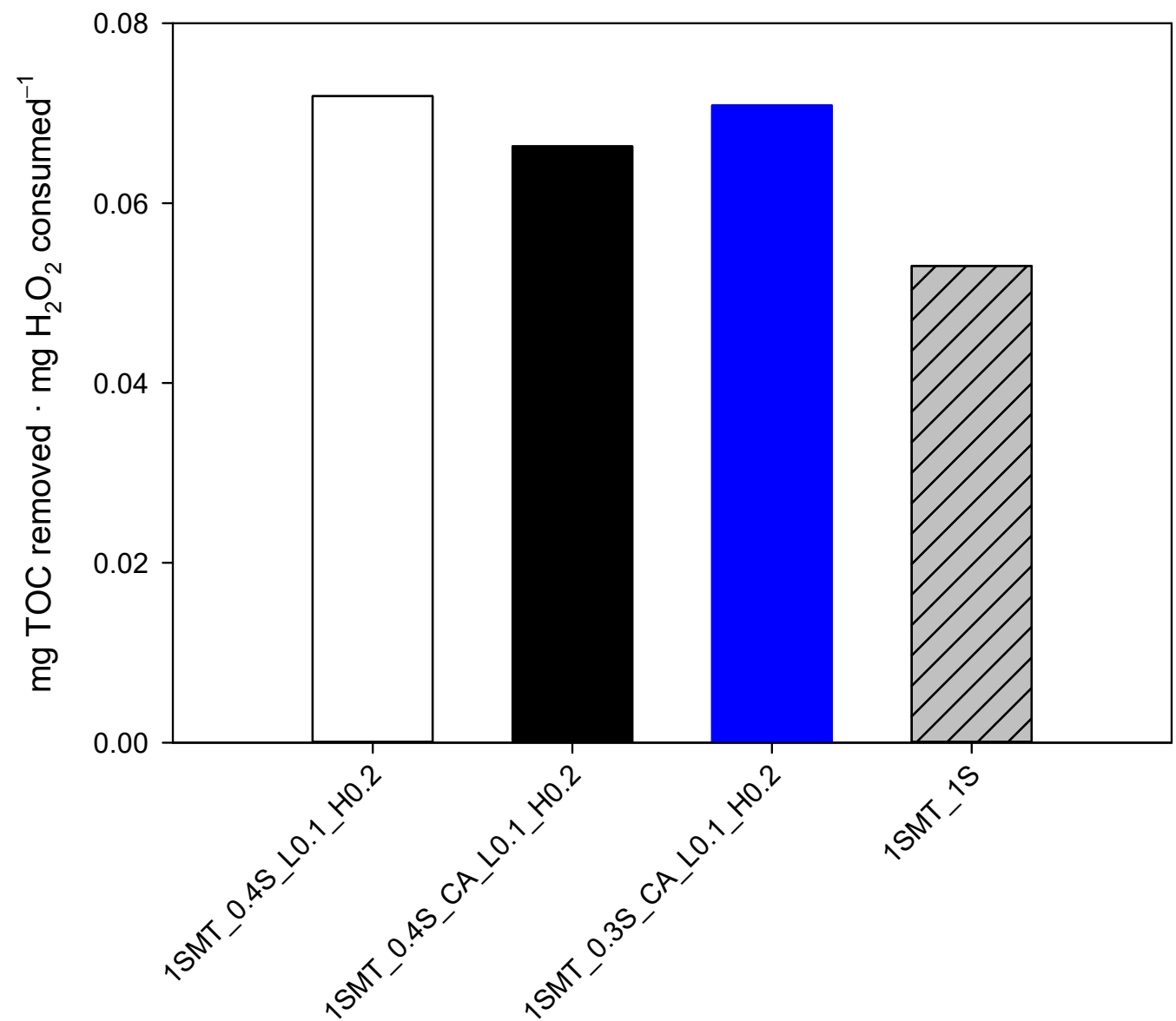

Figure 10. Comparison of the photo-Fenton process efficiency in terms of mg of TOC removed per mg of $\mathrm{H}_{2} \mathrm{O}_{2}$ consumed for each dosage strategy, including the one-shot initial addition of the theoretical stoichiometric concentration.

\section{Conclusions}

This work represents a step forward in the development of a generalized scheme for $\mathrm{H}_{2} \mathrm{O}_{2}$ dosage in photo-Fenton processes. The work has shown that $\mathrm{DO}$ monitoring (a process variable that is inexpensively measured) enables the design of efficient dosage strategies. These strategies were validated against different compounds and mixtures, providing a new insight into this dosage methodology. Hence, the dosage strategy has been redesigned into a simpler and more robust scheme. Despite the different nature of the pollutants studied, the results obtained for PCT, SMT and their mixtures have proved the dosage strategy to be general enough to produce similar degradation rates for the same organic load (TOC). Outcomes have also demonstrated that the dosage strategy could address different organic loads (double concentration of PCT and SMT mixtures) by applying minor modifications (fine tuning). These findings allowed for the improving of the treatment efficiency in terms of TOC removed per $\mathrm{H}_{2} \mathrm{O}_{2}$ consumed in the range from 8 to $15 \%$, which would lead to a significant reduction of operating costs. The implementation of this dosage strategy is also a step forward in process automation, with a substantial positive impact on photo-Fenton TRL (technology readiness level).

The DO slope, which was previously used only for driving the on-off control system of the last treatment stage, was also found to be useful at the transition stage by reducing its duration while achieving the same outcome. This is important, since after the initial addition of $\mathrm{H}_{2} \mathrm{O}_{2}$ shared by both options, the original conception combining open-loop 
and closed-loop dosage control was tested against the use of a closed-loop dosage control system only, which obtained similar results for both contaminants, PCT, SMT and the mixtures.

Further research is underway to explore the tuning of this new dosage scheme beyond the current limiting assumptions. The on-off control has been established according to the range of $\mathrm{H}_{2} \mathrm{O}_{2}$ concentration values recommended in the literature (50-100 $\mathrm{mg} \mathrm{L}^{-1}$ ). Nevertheless, this recommendation does not contemplate the feedback that the DO slope can provide, and this range could be also tuned for further increases to the efficiency of the dosage, for instance by reducing it as the treatment goal approaches.

Author Contributions: Conceptualization, M.P.-M.; Data curation, X.Y.; Formal analysis, M.P.-M.; Funding acquisition, A.C.-R. and M.G.; Investigation, X.Y.; Methodology, X.Y., A.C.-R., S.M.-C. and M.P.-M.; Supervision, M.P.-M.; Writing—original draft, X.Y., A.C.-R., S.M.-C. and M.P.-M.; Writingreview \& editing, A.C.-R., M.G. and M.P.-M. All authors have read and agreed to the published version of the manuscript.

Funding: Financial support received from the Spanish "Ministerio de Ciencia e Innovación" and the European Regional Development Fund, both funding the research Project CEPI (PID2020-116051RBI00) is fully acknowledged. X.Y. particularly acknowledges the State Scholarship Fund of China Scholarship Council (No. 201706950041). S.M.-C. acknowledges the funding provided by the Grant IJC2019-038880-I funded by MCIN/AEI/10.13039/501100011033 and, as appropriate, by “ESF Investing in your future" or by "European Union Next Generation EU/PRTR". A.C.-R. wants to thank SERC Chile (ANID/FONDAP/15110019) and ANID/FONDECYT/1200460.

Conflicts of Interest: The authors declare no conflict of interest.

\section{References}

1. Pignatello, J.J.; Oliveros, E.; MacKay, A. Advanced Oxidation Processes for Organic Contaminant Destruction Based on the Fenton Reaction and Related Chemistry. Crit. Rev. Environ. Sci. Technol. 2006, 36, 1-84. [CrossRef]

2. Tokumura, M.; Morito, R.; Hatayama, R.; Kawase, Y. Iron Redox Cycling in Hydroxyl Radical Generation during the PhotoFenton Oxidative Degradation: Dynamic Change of Hydroxyl Radical Concentration. Appl. Catal. B Environ. 2011, 106, 565-576. [CrossRef]

3. Yamal-Turbay, E.; Graells, M.; Pérez-Moya, M. Systematic Assessment of the Influence of Hydrogen Peroxide Dosage on Caffeine Degradation by the Photo-Fenton Process. Ind. Eng. Chem. Res. 2012, 51, 4770-4778. [CrossRef]

4. Yu, X.; Somoza-Tornos, A.; Graells, M.; Pérez-Moya, M. An Experimental Approach to the Optimization of the Dosage of Hydrogen Peroxide for Fenton and Photo-Fenton Processes. Sci. Total Environ. 2020, 743, 140402. [CrossRef] [PubMed]

5. Ince, N.H. "Critical” Effect of Hydrogen Peroxide in Photochemical Dye Degradation. Water Res. 1999, 33, 1080-1084. [CrossRef]

6. Mirzaei, A.; Chen, Z.; Haghighat, F.; Yerushalmi, L. Removal of Pharmaceuticals from Water by Homo/Heterogonous Fenton-Type Processes-A Review. Chemosphere 2017, 174, 665-688. [CrossRef] [PubMed]

7. Gulkaya, I.; Surucu, G.A.; Dilek, F.B. Importance of H2O2/Fe2+ Ratio in Fenton's Treatment of a Carpet Dyeing Wastewater. J. Hazard. Mater. 2006, 136, 763-769. [CrossRef]

8. Ortega-Gómez, E.; Moreno Úbeda, J.C.; Álvarez Hervás, J.D.; Casas López, J.L.; Santos-Juanes Jordá, L.; Sánchez Pérez, J.A. Automatic Dosage of Hydrogen Peroxide in Solar Photo-Fenton Plants: Development of a Control Strategy for Efficiency Enhancement. J. Hazard. Mater. 2012, 237-238, 223-230. [CrossRef]

9. Audino, F.; Campanyà, G.; Pérez-Moya, M.; Espuña, A.; Graells, M. Systematic Optimization Approach for the Efficient Management of the Photo-Fenton Treatment Process. Sci. Total Environ. 2019, 646, 902-913. [CrossRef]

10. Chu, W.; Chan, K.H.; Kwan, C.Y.; Choi, K.Y. Degradation of Atrazine by Modified Stepwise-Fenton's Processes. Chemosphere 2007, 67, 755-761. [CrossRef]

11. Monteagudo, J.M.; Durán, A.; San Martín, I.; Aguirre, M. Effect of Continuous Addition of H2O2 and Air Injection on FerrioxalateAssisted Solar Photo-Fenton Degradation of Orange II. Appl. Catal. B Environ. 2009, 89, 510-518. [CrossRef]

12. Prieto-Rodríguez, L.; Oller, I.; Zapata, A.; Agüera, A.; Malato, S. Hydrogen Peroxide Automatic Dosing Based on Dissolved Oxygen Concentration during Solar Photo-Fenton. Catal. Today 2011, 161, 247-254. [CrossRef]

13. Yu, X.; Graells, M.; Miralles-Cuevas, S.; Cabrera-Reina, A.; Pérez-Moya, M. An Improved Hybrid Strategy for Online Dosage of Hydrogen Peroxide in Photo-Fenton Processes. J. Environ. Chem. Eng. 2021, 9, 105235. [CrossRef]

14. Cabrera Reina, A.; Miralles-Cuevas, S.; Casas López, J.L.; Sánchez Pérez, J.A. Pyrimethanil Degradation by Photo-Fenton Process: Influence of Iron and Irradiance Level on Treatment Cost. Sci. Total Environ. 2017, 605-606, 230-237. [CrossRef] [PubMed]

15. Martinez, E. Extremum-Seeking Control of Redox Processes in Wastewater Chemical Treatment Plants. Comput. Aided Chem. Eng. 2007, 24, 865-870. [CrossRef] 
16. Santos-Juanes, L.; Sánchez, J.L.G.; López, J.L.C.; Oller, I.; Malato, S.; Sánchez Pérez, J.A. Dissolved Oxygen Concentration: A Key Parameter in Monitoring the Photo-Fenton Process. Appl. Catal. B Environ. 2011, 104, 316-323. [CrossRef]

17. Dalgic, G.; Turkdogan, I.F.; Yetilmezsoy, K.; Kocak, E. Treatment of real paracetamol wastewater by Fenton process. Chem. Ind. Chem. Eng. Q. 2017, 23, 177-186. [CrossRef]

18. Roshanfekr Rad, L.; Irani, M.; Divsar, F.; Pourahmad, H.; Sadegh Sayyafan, M.; Haririan, I. Simultaneous degradation of phenol and paracetamol during photo-Fenton process: Design and optimization. J. Taiwan Inst. Chem. Eng. 2015, 47, 190-196.

19. Nogueira, R.F.P.; Oliveira, M.C.; Paterlini, W.C. Simple and Fast Spectrophotometric Determination of $\mathrm{H}_{2} \mathrm{O}_{2}$ in Photo-Fenton Reactions Using Metavanadate. Talanta 2005, 66, 86-91. [CrossRef]

20. Baffi, R.; Dolch, G.; Garnick, R.; Huang, Y.F.; Mar, B.; Matsuhiro, D.; Niepelt, B.; Parra, C.; Stephan, M. A total organic carbon analysis method for validating cleaning between products in biopharmaceutical manufacturing. J. Parenter. Sci. Technol. 1991, 45, 13-19.

21. Lado Ribeiro, A.R.; Moreira, N.F.F.; Li Puma, G.; Silva, A.M.T. Impact of Water Matrix on the Removal of Micropollutants by Advanced Oxidation Technologies. Chem. Eng. J. 2019, 363, 155-173. [CrossRef]

22. Malato, S.; Fernández-Ibáñez, P.; Maldonado, M.I.; Blanco, J.; Gernjak, W. Decontamination and Disinfection of Water by Solar Photocatalysis: Recent Overview and Trends. Catal. Today 2009, 147, 1-59. [CrossRef]

23. Zapata, A.; Oller, I.; Bizani, E.; Sánchez-Pérez, J.A.; Maldonado, M.I.; Malato, S. Evaluation of Operational Parameters Involved in Solar Photo-Fenton Degradation of a Commercial Pesticide Mixture. Catal. Today 2009, 144, 94-99. [CrossRef]

24. Ballesteros Martín, M.M.; Sánchez Pérez, J.A.; Casas López, J.L.; Oller, I.; Malato Rodríguez, S. Degradation of a Four-Pesticide Mixture by Combined Photo-Fenton and Biological Oxidation. Water Res. 2009, 43, 653-660. [CrossRef]

25. Gernjak, W.; Fuerhacker, M.; Fernández-Ibañez, P.; Blanco, J.; Malato, S. Solar Photo-Fenton Treatment-Process Parameters and Process Control. Appl. Catal. B Environ. 2006, 64, 121-130. [CrossRef]

26. Audino, F.; Conte, L.O.; Schenone, A.V.; Pérez-Moya, M.; Graells, M.; Alfano, O.M. A Kinetic Study for the Fenton and PhotoFenton Paracetamol Degradation in an Annular Photoreactor. Environ. Sci. Pollut. Res. 2019, 26, 4312-4323. [CrossRef] [PubMed]

27. Cabrera Reina, A.; Miralles-Cuevas, S.; Cornejo, L.; Pomares, L.; Polo, J.; Oller, I.; Malato, S. The influence of location on solar photo-Fenton: Process performance, photoreactor scaling-up and treatment cost. Renew. Energy 2020, 145, 1890-1900. [CrossRef] 